Published in final edited form as:

J Am Chem Soc. 2005 October 26; 127(42): 14594-14595.

\title{
Direct Repair of the Exocyclic DNA Adduct 1,N6-Ethenoadenine by the DNA Repair AlkB Proteins
}

\author{
Yukiko Mishina, Cai-Guang Yang, and Chuan He \\ Department of Chemistry, The University of Chicago, 5735 South Ellis Avenue, Chicago, Illinois \\ 60637
}

DNA is challenged by endogenous or environmental alkylation agents that modify heterocyclic bases and backbones. ${ }^{1}$ Many of these lesions can have mutagenic or cytotoxic consequences, and thus they must be promptly detected and repaired. Recently, it was found that Escherichia coli $\mathrm{AlkB}$ and its human homologues catalyze a unique oxidative repair of alkylated DNA bases. E. coli AlkB belongs to a superfamily of iron-/ $\alpha$-ketoglutarate-dependent dioxygenases. 2 This protein and its two human homologues have been shown to oxidize the methyl groups of $\mathrm{N}^{1}$-methyladenine and $\mathrm{N}^{3}$-methylcytosine in single-stranded DNA (ssDNA), doublestranded DNA (dsDNA), and single-stranded RNA (ssRNA). ${ }^{3}$ The corresponding alcohol products spontaneously decompose in water to give the undamaged bases and formaldehyde. These proteins have also been shown to directly repair $\mathrm{N}^{3}$-methylthymine and $\mathrm{N}^{1}$ methylguanine lesions through the same proposed mechanism. ${ }^{3 \mathrm{e}, 4}$ The native iron(II)containing AlkB has been isolated from E. coli and spectroscopically characterized. ${ }^{5}$

The base lesions repaired by AlkB are generated in unpaired bases in DNA. ${ }^{1 b, c}$ These lesions can no longer form Watson-Crick base pairs with the opposite bases and are cytotoxic. The AlkB proteins possess the ability to specifically locate the weakened base pairs containing these modifications. ${ }^{6}$ Exocyclic DNA adducts, such as $1, \mathrm{~N}^{6}$-ethenoadenine $(\varepsilon \mathrm{A}), 3, \mathrm{~N}^{4}$ ethenocytosine $(\varepsilon \mathrm{C})$, and $1, \mathrm{~N}^{2}$-ethenoguanine $(\varepsilon \mathrm{G})$, also block Watson-Crick base pairing (Scheme 1). ${ }^{7}$ These adducts arise from treatment of DNA with chloroethylene oxide or chloroacetaldehyde. In particular, it has been shown that lipid peroxidation products generated under oxidative stress lead to the formation of $\varepsilon \mathrm{A}, \varepsilon \mathrm{C}$, and, $\varepsilon \mathrm{G}, \mathrm{b}, \mathrm{d}$ which have been linked to the cytotoxic and genotoxic effects observed for lipid peroxidation.

We speculated that the exocyclic lesion $\varepsilon$ A may serve as a substrate for AlkB. The putative iron(IV)-oxo intermediate formed from the reaction of Fe(II)-AlkB with dioxygen and cofactor $\alpha$-ketoglutarate could oxidize the exocyclic section of $\varepsilon$ A. For instance, an epoxidation of the exocyclic double bond would afford epoxide 1 , which can be hydrolyzed by water to produce the repaired base and glyoxal (Figure 1).

To test this hypothesis, $\varepsilon$ A was incorporated into a 3-mer DNA T( $(\varepsilon A) T$. This substrate $(0.1$ $\mathrm{mM})$ was treated with E. coli $\mathrm{AlkB}(0.01 \mathrm{mM}, 10 \mathrm{~mol} \%)$ under standard conditions in $100 \mu \mathrm{L}$ of buffer solution at $\mathrm{pH} 7.0$ for $1 \mathrm{~h} .{ }^{3 \mathrm{a}, \mathrm{d}, \mathrm{h}}$ The HPLC analysis of the product mixture showed the complete disappearance of the $\mathrm{T}(\varepsilon \mathrm{A}) \mathrm{T}$ peak and an appearance of a new peak that represents TAT (Figure 2A). TAT was added into the same mixture, which was then analyzed by HPLC. An intensity increase in the new peak confirmed that TAT was obtained as the final product. A control experiment was performed under the exact same conditions with $\mathrm{T}(\varepsilon \mathrm{A}) \mathrm{T}, \mathrm{Fe}$ $\left(\mathrm{NH}_{4}\right)_{2}\left(\mathrm{SO}_{4}\right)_{2}, \alpha$-ketoglutarate, and ascorbate in MES or HEPES buffer while excluding AlkB. HPLC analysis of this mixture indicated that no repair reaction had occurred in the absence of

E-mail: chuanhe@uchicago.edu. 
AlkB (Figure 2B). The identities of TAT and TeAT in solutions were further confirmed by MALDI mass spectrometry (graphs $\mathrm{C}$ and D of Figure 2).

We next studied the $\mathrm{pH}$ dependency of this repair reaction. Quantitative conversion of $\mathrm{T}(\varepsilon \mathrm{A})$ $\mathrm{T}$ to TAT was observed with $5 \mathrm{~mol} \%$ of AlkB after 5 min incubation at both $\mathrm{pH} 4.0$ and 5.0 (Figure 3A). Complete repair was also observed at pH 6.0 after 20 min reaction (Figure 3B). At neutral $\mathrm{pH}$, the reaction proceeds catalytically as 8 turnovers were achieved after $30 \mathrm{~min}$. Doubling the concentration of AlkB led to an increase of the repair rate by approximately 2fold. The $\mathrm{pH}$-rate profile of this repair reaction may suggest an acid-assisted step in the repair process. The kinetics shown here and factors that may determine the $\mathrm{pH}$ dependency will be carefully studied in the future.

A longer DNA, TTTTT( $\varepsilon$ A)TTTTT, with $\varepsilon$ A incorporated in the middle of an 11-mer strand was prepared and tested as the substrate as well. After reaction with AlkB under standard conditions, the DNA was digested to nucleosides, ${ }^{9 \mathrm{a}}$ and HPLC analysis of the digested $\mathrm{DNA}^{9 \mathrm{~b}}$ confirmed that treatment with $5 \mathrm{~mol} \%$ of AlkB led to complete repair of $\varepsilon \mathrm{A}$ to $\mathrm{A}$ in 30 min at both pH 6.0 and 7.0 (Figure S1). In addition, we were able to detect glyoxal, a small molecule that would be produced from the oxidative repair process proposed in Figure 1, by using a previously established procedure (Figures S2 and S3). ${ }^{10}$

$\mathrm{ABH} 3$ also repairs $\mathrm{T}(\varepsilon \mathrm{A}) \mathrm{T}$, but with a much lower activity compared to that of AlkB. Treatment of varying concentrations of $\mathrm{ABH} 3$ (10 and $50 \mathrm{~mol} \%$, and 1 equiv) with $\mathrm{T}(\varepsilon \mathrm{A}) \mathrm{T}$ for $16 \mathrm{~h}$ at $\mathrm{pH} 6.0$ at room temperature (to prevent aggregation of $\mathrm{ABH} 3$ ) led to a portion of the $\mathrm{T}(\varepsilon \mathrm{A}) \mathrm{T}$ $(16,51$, and $67 \%$, respectively) being converted into TAT (Figures S4) as determined by HPLC analysis. It has been shown that the recombinant $\mathrm{ABH} 3$ overexpressed from $E$. coli has only $2 \%$ of AlkB's activity in vitro when assayed with $\mathrm{N}^{1}$-methyladenine. ${ }^{3 \mathrm{e}}$ The reason for the low activity observed for the human homologues of AlkB is unclear. $3 \mathrm{e}, \mathrm{g}, \mathrm{h}$ The biological relevance and physiological importance of the activity reported here for $\mathrm{ABH} 3$ need to be carefully evaluated in the future.

The $1, \mathrm{~N}^{6}$-ethenoadenine ( $(\mathrm{A}), 3, \mathrm{~N}^{4}$-ethenocytosine $(\varepsilon \mathrm{C})$, and $1, \mathrm{~N}^{2}$ - and $\mathrm{N}^{2}, 3$-ethenoguanine $(\varepsilon \mathrm{G})$ adducts are produced from endogenous metabolic processes, such as lipid peroxidation, in humans. ${ }^{8}$ These exocyclic adducts have miscoding potentials that can lead to mutagenic consequences. For instance, $\mathrm{G}, \mathrm{T}$, and $\mathrm{A}$ are readily incorporated opposite $\varepsilon \mathrm{C}$ during DNA synthesis; ${ }^{11 \mathrm{a}, \mathrm{b}}$ formation of $\varepsilon \mathrm{A}$ can lead to a predominant $\varepsilon \mathrm{A} \rightarrow \mathrm{G}$ transition. ${ }^{11 \mathrm{c}, \mathrm{d}}$ It was found that $\varepsilon \mathrm{A}$ and $\varepsilon \mathrm{C}$ are particularly mutagenic in mammalian cells. These mutations, upon accumulation, contribute to genetic alterations that can lead to aging and disease. The repair of exocyclic DNA adducts has been shown to be mediated by DNA base glycosylases. ${ }^{12} \mathrm{We}$ demonstrated here that one of these lesions, $\varepsilon \mathrm{A}$, can be directly reversed by E. coli AlkB and human $\mathrm{ABH} 3$ in vitro. This result suggests that the AlkB proteins may play a role in eliminating exocyclic DNA base adducts, and thus suppressing the cytotoxic and mutagenic consequences derived from the damage. Since the AlkB proteins have been shown to work on ssDNA, dsDNA, and RNA substrates, ${ }^{3}$ they may play different/complementary roles to the glycosylases to fix exocyclic DNA lesions. More thorough investigations on the mechanism and physiological importance of the repair process discovered here are in progress.

\section{Supplementary Material}

Refer to Web version on PubMed Central for supplementary material.

\section{Acknowledgment}

We thank Dr. J. Piccirilli for the use of the DNA synthesizer, and Mr. D. Wolfgeher for assistance with the MALDI experiments. This research was supported by the G\&P Foundation for Cancer Research (C.H.), the W. M. Keck Foundation Distinguished Young Scholars Program (C.H.), and the National Institutes of Health (GM071440). C.H. 
is also a Searle Scholar, an Arnold and Mabel Beckman Foundation Young Investigator, and a Research Corporation Cottrell Scholar.

\section{References}

1. a Lindahl T, Sedgewick B, Sekiguchi M, Nakabeppu Y. Annu. Rev. Biochem 1988;57:133-157. [PubMed: 3052269] b Sedgwick B. Nat. Rev. Mol. Cell Biol 2004;5:148-157. [PubMed: 15040447] c Drabløs F, Feyzi E, Aas PA, Vaagbø CB, Kavli B, Bratlie MS, Peña-Diaz J, Otterlei M, Slupphaug G, Krokan HE. DNA Repair 2004;3:1389-1407. [PubMed: 15380096] d Myers LC, Terranova MP, Ferentz AE, Wagner G, Verdine GL. Science 1993;261:1164-1167. [PubMed: 8395079]

2. Aravind L, Koonin EV. GenomeBiology 2001;2:007.001-007.008.

3. a Trewick S, Henshaw TF, Hausinger RP, Lindahl T, Sedgwick B. Nature 2002;419:174-178. [PubMed: 12226667] b Falnes PØ, Johansen RF, Seeberg E. Nature 2002;419:178-182. [PubMed: 12226668] c Koivisto P, Duncan T, Lindahl T, Sedgwick B. J. Biol. Chem 2003;278:44348-44354. [PubMed: 12944387] d Welford RWD, Schlemminger I, McNeill LA, Hewitson KS, Schofield CJ. J. Biol. Chem 2003;278:10157-10161. [PubMed: 12517755] e Koivisto P, Robins P, Lindahl T, Sedgwick B. J. Biol. Chem 2004;279:40470-40474. [PubMed: 15269201] f Ougland R, Zhang CM, Liiv A, Johansen RF, Seeberg E, Hou YM, Remme J, Falnes PØ. Mol. Cell 2004;16:107-116. [PubMed: 15469826] g Aas PA, Otterlei M, Falnes PØ, Vaagbo CB, Skorpen F, Akari M, Sundheim O, Bjørås M, Slupphaug G, Seeberg E, Krokan H. Nature 2003;421:859-863. [PubMed: 12594517] h Duncan T, Trewick SC, Koivisto P, Bates PA, Lindahl T, Sedgwick B. Proc. Natl. Acad. Sci. U.S.A 2002;99:16660-16665. [PubMed: 12486230]

4. a Delaney JC, Essigmann JM. Proc. Natl. Acad. Sci. U.S.A 2004;101:14051-14056. [PubMed: 15381779] b Falnes PØ. Nucleic Acids Res 2004;32:6260-6267. [PubMed: 15576352]

5. Mishina Y, Chen LX, He C. J. Am. Chem. Soc 2004;126:16930-16936. [PubMed: 15612731]

6. a Mishina Y, He C. J. Am. Chem. Soc 2003;125:8730-8731. [PubMed: 12862460] b Mishina Y, Lee C-HJ, He C. Nucleic Acids Res 2004;32:1548-1554. [PubMed: 15004242]

7. a Choi JH, Pfeifer GP. Mutat. Res 2004;568:245-256. [PubMed: 15542111] b Gros L, Ishchenko AA, Saparbaev M. Mutat. Res 2003;531:219-229. [PubMed: 14637257] c Douki T, Odin F, Caillat S, Favier A, Cadet J. Free Radical Biol. Med 2004;37:62-70. [PubMed: 15183195] d Speina E, Kierzek AM, Tudek B. Mutat. Res 2003;531:205-217. [PubMed: 14637256]

8. a Chung FL, Chen HJ, Nath RG. Carcinogenesis 1996;17:2105-2111. [PubMed: 8895475] b Pollack M, Oe T, Lee SH, Silva Elipe MV, Arison BH, Blair IA. Chem. Res. Toxicol 2003;16:893-900. [PubMed: 12870892] c Nair J, Barbin A, Guichard Y, Bartsch H. Carcinogenesis 1995;16:613-617. [PubMed: 7697821]

9. a Crain PF. Methods Enzymol 1990;193:782-790. [PubMed: 1706062] b Pomerantz SC, McCloskey JA. Methods Enzymol 1990;193:796-824. [PubMed: 1706064]

10. Lapolla A, Flamini R, Tonus T, Fedele D, Senesi A, Reitano R, Marrotta E, Pace G, Seraglia R, Traldi P. Rapid Commun. Mass Spectrom 2003;17:876-878. [PubMed: 12672144]

11. a Moriya M, Zhang W, Johnson F, Grollman AP. Proc. Natl. Acad. Sci. U.S.A 1994;91:11899-11903. [PubMed: 7991554] b Basu AK, Wood ML, Niedernhofer LJ, Ramos LA, Essigmann JM. Biochemistry 1993;32:12793-12801. [PubMed: 8251500] c Pandya GA, Moriya M. Biochemistry 1996;35:11487-11492. [PubMed: 8784204] d Levine RL, Yang IY, Hossain M, Pandya GA, Grollman AP, Moriya M. Cancer Res 2000;60:4098-4104. [PubMed: 10945616]

12. a Asaeda A, Ide H, Asagoshi K, Matsuyama S, Tano K, Murakami A, Takamori Y, Kubo K. Biochemistry 2000;39:1959-1965. [PubMed: 10684645] b O'Connor TR, Laval J. Biochem. Biophys. Res. Commun 1991;176:1170-1177. [PubMed: 1645538] c Lau AY, Wyatt MD, Glassner BJ, Samson LD, Ellenberger T. Proc. Natl. Acad. Sci. U.S.A 2000;97:13573-13578. [PubMed: 11106395] d Dosanjh MK, Roy R, Mitra S, Singer B. Biochemistry 1994;33:1624-1628. [PubMed: 8110764] e Saparbaev M, Laval J. Proc. Natl. Acad. Sci. U.S.A 1998;95:8508-8513. [PubMed: 9671708] f Roy R, Kennel SJ, Mitra S. Carcinogenesis 1996;17:2177-2182. [PubMed: 8895486] 


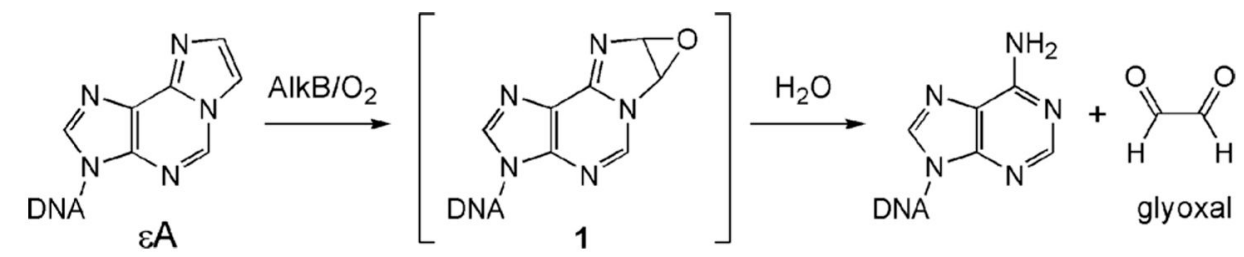

Figure 1.

Proposed repair of $\varepsilon A$ in DNA by the AlkB proteins. 

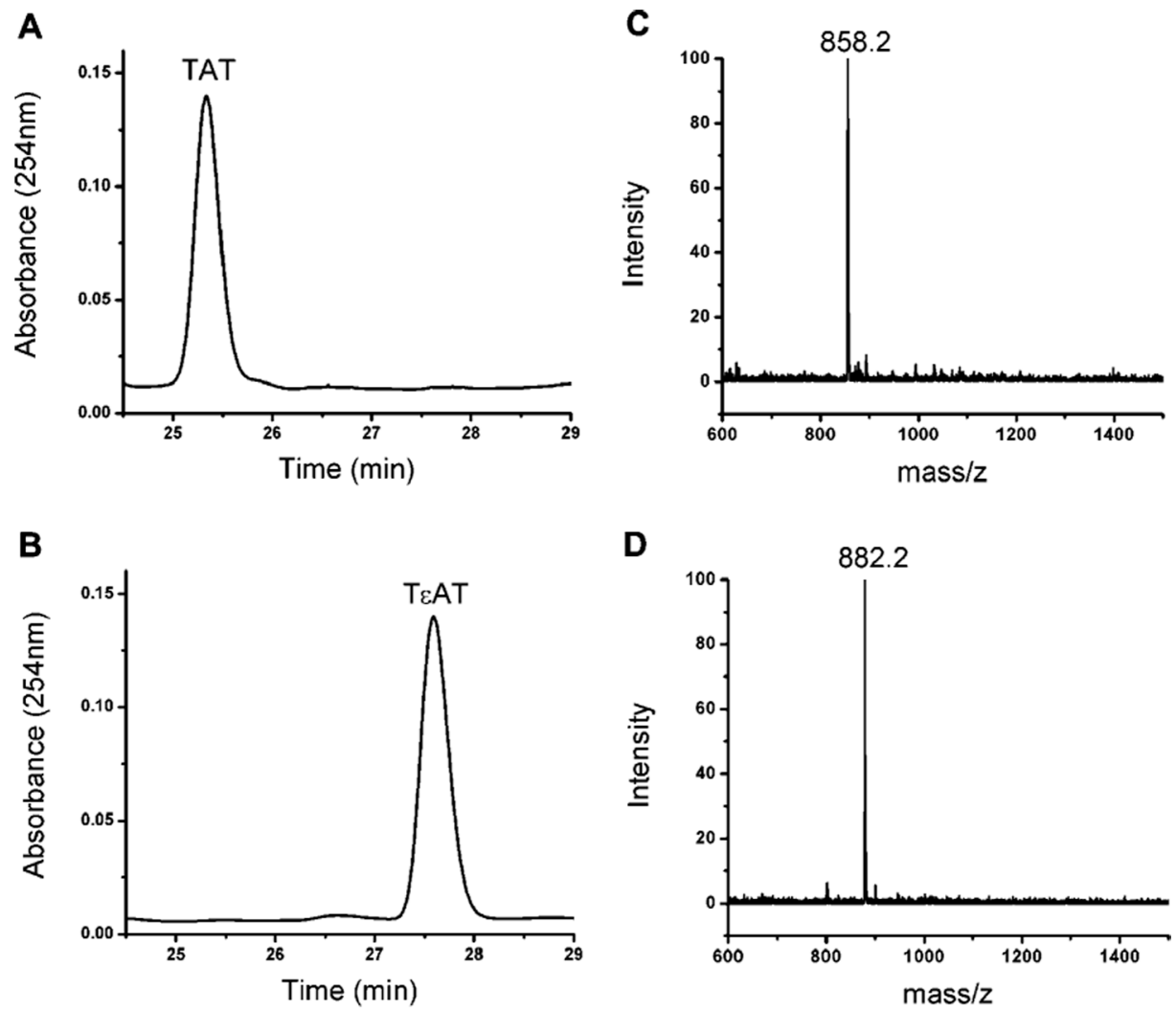

Figure 2.

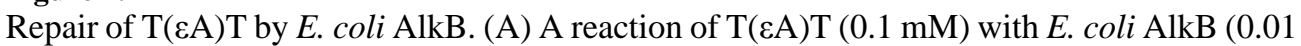
$\mathrm{mM}$ ) under the standard repair conditions (50 mM MES or HEPES, $0.2 \mathrm{mM} \mathrm{Fe}$

$\left(\mathrm{NH}_{4}\right)_{2}\left(\mathrm{SO}_{4}\right)_{2}, 2.6 \mathrm{mM} \alpha$-ketoglutarate, $5.2 \mathrm{mM}$ ascorbate) at $\mathrm{pH} 7.0$ for $1 \mathrm{~h}$ at $37^{\circ} \mathrm{C}$ led to the formation of TAT, which was resolved by HPLC and detected at $\mathrm{A}_{254}$. (B) A control experiment under the same conditions as (A) but in the absence of AlkB gave only the starting material T(EA)T. (C) The reaction mixture of (A) was analyzed by MALDI-TOF mass spectrometry. The negative molecular peak of TAT at 858.2 was detected. (D) The mixture of the control reaction in (B) was analyzed by MALDI-TOF mass spectrometry, and the negative molecular peak of $\mathrm{T}(\varepsilon \mathrm{A}) \mathrm{T}$ at 882.2 was observed. 


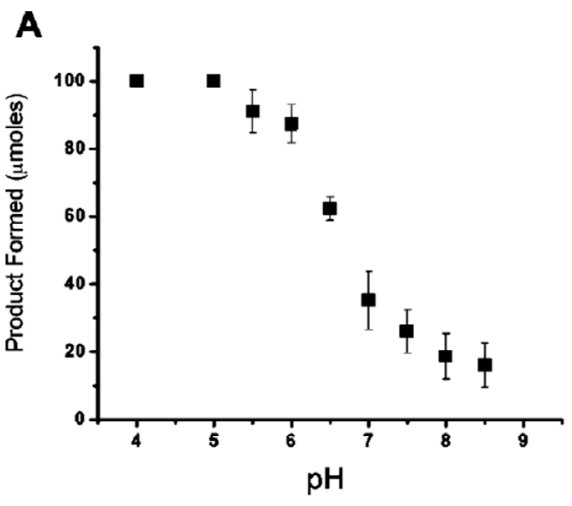

C

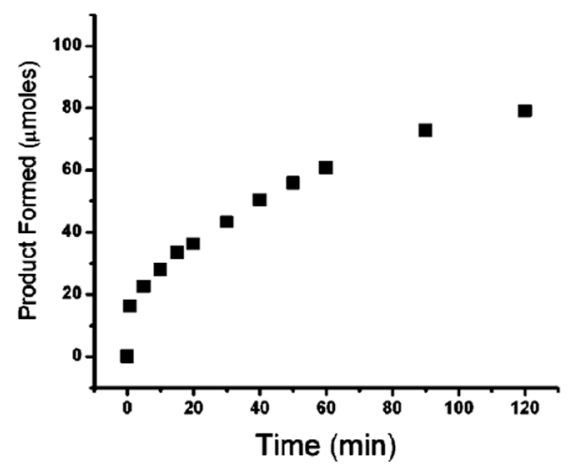

B

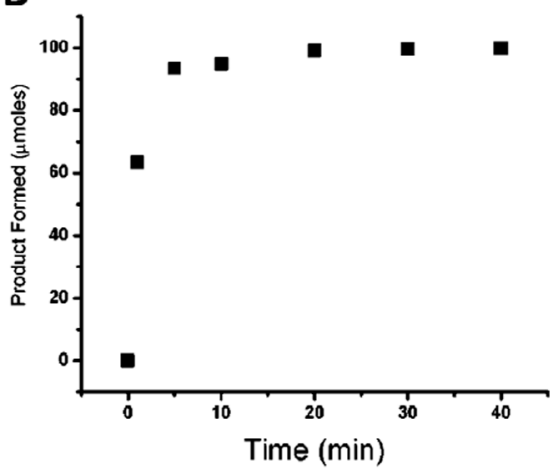

D

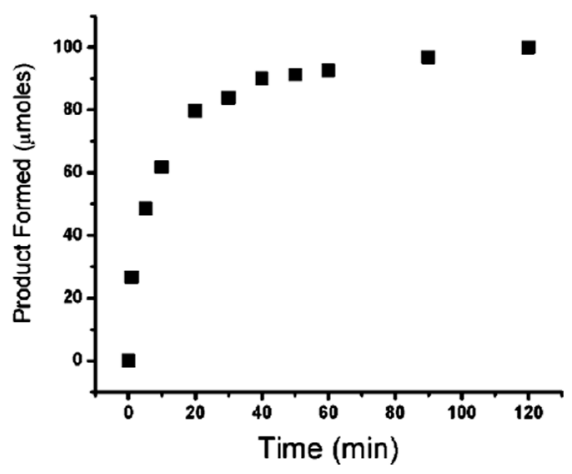

Figure 3.

The $\mathrm{pH}$ dependency and time courses for the repair of $\mathrm{T}(\varepsilon \mathrm{A}) \mathrm{T}$ by AlkB. (A) T(EA)T $(0.1 \mathrm{mM})$ was treated with $5 \mu \mathrm{M}$ of $\mathrm{AlkB}$ at different $\mathrm{pH}$, and the reactions were quenched after 5 min. Time courses for reactions between $0.1 \mathrm{mM}$ of T( $\varepsilon \mathrm{A}) \mathrm{T}$ and $\mathrm{AlkB}$ at $37{ }^{\circ} \mathrm{C}$; (B) $5 \mu \mathrm{M} \mathrm{AlkB}$ at pH 6.0, (C) $5 \mu \mathrm{M}$ AlkB at pH 7.0, and (D) $10 \mu \mathrm{M}$ of AlkB with pH 8.0 are also shown. Standard repair conditions were used with MES (for $\mathrm{pH}$ 4.0-6.5) or HEPES (for $\mathrm{pH} 7.0-8.5$ ) as the buffers in $100 \mu \mathrm{L}$ of solution. 
<smiles>O=[N+]([O-])n1cnc2c1ncn1ccnc21</smiles>

$1, N^{6}$-ethenoadenine<smiles>O=c1n([N+](=O)[O-])ccc2nccn12</smiles>

$3, N^{4}$-ethenocytosine<smiles>N#CCn1cnc2c(=O)n3cc[nH]c3nc21</smiles>

$1, N^{2}$-ethenoguanine

Scheme 1.

Exocyclic DNA Adducts 